\title{
EPIDEMIOLOGY OF SPINE TRAUMA IN PATIENTS WITH POLYTRAUMA
}

\author{
EPIDEMIOLOGIA DE TRAUMA DA COLUNA EM PACIENTES COM POLITRAUMATISMO
}

\author{
EPIDEMIOLOGÍA DEL TRAUMA DE COLUMNA VERTEBRAL EN PACIENTES \\ POLITRAUMATIZADOS
}

Luis Muñiz Luna', Ricardo de Jesús Altamirano Mendoza', Yuri Montero Oropeza'

1. Instituto Mexicano del Seguro Social, Advanced Specialty Medical Unit “Hospital de Traumatología y Ortopedia Lomas Verdes, Spine Surgery Service, Naucalpan de Juárez, Estado de México, Mexico.

\begin{abstract}
Objective: To determine the epidemiology of spine trauma in patients with polytrauma. Methods: The database of the service of polyfractured patients was reviewed from January to December 2015, 334 patients in total. Among them, 56 had spinal injury, of which 38 patients were included in the study. Results: Of the patients with polytraumatism, 16.77\% had spinal cord injury. Mechanism of injury: fall 63.16\%, traffic accidents $21.05 \%$, running over $10.53 \%$. Injury conditions: occupational 36.84\%, at home $23.68 \%$, traffic accident $15.79 \%$, public road $13.16 \%$, motorcycle accident $5.26 \%$, of which $13.16 \%$ had consumed alcoholic beverages. Total with neurological injury $23.68 \%$, incomplete lesion 18.42\%. Injured vertebral segment: lumbar 76.32\%, thoracic 31.58\%, and cervical 7.89\%. Associated injuries: upper limbs 47.37\%, lower limbs $42.11 \%$, pelvis $36.84 \%$, thorax $34.21 \%$, craniofacial $31.58 \%$, abdomen $21.05 \%$. Treatment: instrumentation $71.05 \%$, orthoses $26.32 \%$. Infection rate of $22.22 \%$. Conclusions: The most common mechanism of injury was falls in the working environment, almost one fourth presented neurological damage, the most affected segment was the lumbar associated with injury of the lower limbs in $50 \%$, with one fourth of patients that undergone intervention presenting infection. It is in the workplace, at home and in the transit where preventive measures must be reinforced to reduce the incidence of injuries in working age patients.
\end{abstract}

Keywords: Spinal injuries/epidemiology; Spinal fractures; Multiple trauma.

\section{RESUMO}

Objetivo: Determinar a epidemiologia de trauma de coluna em pacientes com politraumatismo. Métodos: O banco de dados do serviço de polifraturados foi revisado, de janeiro a dezembro de 2015, com 334 pacientes no total. Entre eles, 56 apresentavam lesão da coluna vertebral, dos quais 38 pacientes foram incluídos no estudo. Resultados: Dos pacientes com politraumatismo, 16,77\% tinham lesão de coluna vertebral. Mecanismo da lesão: queda 63,16\%, acidentes de trânsito 21,05\%, atropelamento 10,53\%. Condições de lesão: ocupacional 36,84\%, em casa $23,68 \%$, acidente de trânsito 15,79\%, via pública 13,16\%, acidente de motocicleta 5,26\%, sendo que do total destes, $13,16 \%$ haviam consumido bebida alcoólica. Total com lesão neurológica 23,68\%, lesão incompleta 18,42\%. Segmento vertebral lesionado: lombar 76,32\%, torácico 31,58\%, cervical 7,89\%. Lesões associadas: membros superiores 47,37\%, membros inferiores 42,11\%, pelve 36,84\%, tórax 34,21\%, craniofacial 31,58\%, abdome 21,05\%. Tratamento: Instrumentação 71,05\%, órteses 26,32\%. Taxa de infecção de 22,22\%. Conclusões: 0 mecanismo mais comum de lesão foi a queda no ambiente de trabalho, quase um quarto apresentou danos neurológicos, o segmento mais afetado foi o lombar, associado a lesão dos membros inferiores em 50\%, com um quarto dos pacientes submetidos à intervenção apresentando infecção. É no ambiente de trabalho, em casa e no trânsito, onde as medidas preventivas devem ser reforçadas para reduzir a incidência de lesões em pacientes em idade produtiva.

Descritores: Traumatismos da coluna vertebral/epidemiologia; Fraturas da coluna vertebral; Traumatismo múltiplo.

\section{RESUMEN}

Objetivo: Conocer la epidemiología del trauma de columna en pacientes politraumatizados. Métodos: Se revisó la base de datos del servicio de polifracturados, de enero a diciembre del 2015, con 334 pacientes en total. De éstos, 56 presentaban alguna lesión en la columna vertebral, de los cuales 38 pacientes fueron captados para el estudio. Resultados: De los pacientes politraumatizados, 16,77\% presentaron alguna lesión de columna. Mecanismo de lesión: caída 63,16\%, accidentes de tránsito 21,05\%, atropellamiento 10,53\%. Condiciones de lesión: laboral 36,84\%, hogar 23,68\%, choque en automóvil 15,79\%, vía pública 13,16\%, accidente en motocicleta 5,26\%, y del total de éstos, en estado etílico 13,16\%. Total con lesión neurológica 23,68\%, lesión incompleta 18,42\%. Segmento vertebral lesionado: Lumbar 76,32\%, torácico 31,58\%, cervical 7,89\%. Lesiones asociadas: miembros torácicos 47,37\%, miembros pélvicos 42,11\%, pelvis 36,84\%, tórax 34,21\%, craneofacial 31,58\%, abdomen 21,05\%. Tratamiento: Instrumentación 71,05\%, ortesis 26,32\%. Tasa de infección del 22,22\%. Conclusiones: El mecanismo de lesión más frecuente fue caída en el ámbito laboral, casi una cuarta parte presentó daño neurológico, el segmento más afectado fue el lumbar, asociado a lesión en miembros pélvicos en el 50\%, con una cuarta parte de los pacientes intervenidos cursando con infección. Es en el ámbito laboral, hogar y tránsito donde se deben reforzar las medidas preventivas para disminuir la incidencia de lesiones en pacientes en edad productiva.

Descriptores: Traumatismos vertebrales/epidemiología; Fracturas de la columna vertebral; Traumatismo múltiple.

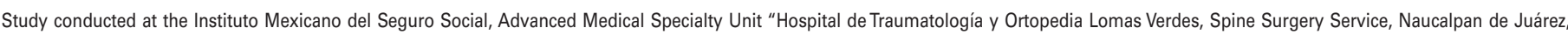
Estado de México, Mexico.

Correspondence: Av. Lomas Verdes \#2165, col. Santiago Occipaco. 53250. Naucalpan de Juárez, Estado de México, Piso 10, consultorio 1015. Mexico, DF. orthos_trauma@yahoo.com.mx 


\section{INTRODUCTION}

There is little evidence published about the injurious conditions and injuries associated with spine trauma in polyfractured patients. ${ }^{1-5}$ Little is said about patients who suffer from multiple trauma in basic orthopedic and spine surgery books. ${ }^{6-8}$ Patients with spinal trauma are a group who require special attention for their treatment and rehabilitation because of the costs that they generate in the medical, economic, and social environments. In addition to presenting various injuries, it is not uncommon for less serious inadvertent injuries to occur. In general, these patients require a prolonged hospital stay, several surgical procedures, and a long recovery time, which means more consultations, more lost work (in the case or working patients), and greater involvement of relatives as caregivers during recovery.

The objective of this study was to identify the most common injury mechanisms associated with polyfractured patients with spine injuries, as well as the type and severity of vertebral injuries and other associated injuries, treatments, and complications, and to assist with suspected associated injuries, as well as to determine prognoses for patients with spinal injuries and polytraumatized patients.

\section{METHODS}

The clinical records of patients admitted to the Polyfracture Service of the Advanced Medical Specialty Unit of the Hospital de Traumatología y Ortopedia "Lomas Verdes", from January 1, 2015 to December 31, 2015, including a total of 334 patients, was reviewed. Patients older than 16 years of age were admitted to this service with a) fractures of the pelvis or b) patients with injuries to two or more segments divided into 1) spine, 2) thoracic member (shoulder, elbow, and wrist), 3) hand, 4) hip, femur, and knee, and 5) tibia, ankle, and foot. Upon leaving the Emergency Department, these patients are admitted to the hospital wards or intensive care units.

The following inclusion criteria were used for the study: a) patients admitted to the Polyfracture Service during the established time period; b) patients with spine lesions at the cervical, thoracic, or lumbar levels, regardless of the number of vertebrae or segments or the type of fracture as defined by the $A O$ classification $(A, B$, or C); c) patients with recent vertebral lesions attributable to the same injury mechanism causing lesions in other segments; d) patients whose vertebral lesions were confirmed by computed tomography. The exclusion criteria were: a) patients with non-recent vertebral lesions detected at the time of review of imaging studies; b) patients with vertebral lesions not attributable to the same injury mechanism that caused lesions in other segments; and c) patients with injuries to the lumbar transverse processes attributable to the mechanism of an avulsion lesion secondary to a pelvic injury.

We selected 56 patients initially qualified with vertebral lesions, of which we eliminated two for presenting non-recent vertebral injuries, two patients not eligible for IMSS due to the lack of available case files, three deceased patients for having case files not open for review, four patients with avulsion fractures of the lumbar vertebral transverse process secondary to pelvic lesions, and seven patients whose case files were not available in the clinical archives of the hospital at the time of the review.

The sample included 38 patients whose physical files, electronic files, and electronic desk studies were reviewed. The following data were recorded: sex, age, date of the accident, injury mechanism (classified as motor vehicle accident, fall, being run over, crushed, or gunshot wound), the conditions of the car accident (workplace, home, suicide attempt, motorcycle accident), intoxication from alcohol at the time of the accident, time of the accident (classified as: morning [from 06:00 to 13:59], afternoon [from 14:00 to 21:59], and night [22:00 to 05:59]), date of admission to the unit, date of discharge from the unit, vertebral injury diagnosis, segment affected (cervical, thoracic, lumbar), neurological state on the Frankel scale, type of lesion according to the $A O$ classification (A, B, or C), diagnosis of associated injuries, injuries divided by segment (craniofacial trauma, chest trauma, abdominal trauma, fractures of the upper limbs, pelvic injury, fracture of the lower limbs), type of management for the vertebral injury (instrumentation or conservative management), and complications (wound dehiscence, wound infection). Microsoft Excel was used for the arithmetic and statistical calculations. Because this study was retrospective and descriptive, it did not need to be reviewed by the Institutional Review Board. The study did not require informed consent because the study was retrospective, descriptive, observational, and non-interventional. This research study was safe, with a risk lower than the minimum standards for the regulation of health research established by the Instituto Mexicano Del Seguro Social [Mexican Social Security Institute], based on the provisions of the General Health Law, published in the Official Gazette of the Federation on February 7, 1984, and its amendments, article 2 section VII, article 41 Bis, and Title Five Sole Chapter. The data obtained from the database were used only by the research team to maintain confidentiality and protect the identity of the patients.

This research study complies with the International Standard of the Helsinki Declaration of the 18th World Medical Association General Assembly, Helsinki, Finland, June 1964, and the General Assembly, Fortaleza, Brazil, 2012; with the regulations of the General Health Law for health research material currently in force; and with the fundamental principles of bioethics: beneficence, non-maleficence, justice, and self-determination and autonomy, as well as with the research standards of the IMSS.

\section{RESULTS}

Of the 56 patients included in the study, 50 had some recent traumatic spinal injury, not attributable to avulsion of the transverse process in pelvic lesions, which represents $14.97 \%$ of the registered polyfractured patients. The average age of the 38 patients included in the sample was 40.3 years, with a mode of 23 and a median of 35 . Figure 1 shows the distribution by sex, with a male to female ratio of 5.3:1. The average number of days in the hospital was 12.7, mode 11, median 12. (Figure 1)

\section{Mechanism and circumstances of the injury}

The most common injury mechanism was falls, in $63 \%$ of the cases (24 patients), followed by motor vehicle accidents, being run over, being crushed, and gunshot wounds, with one patient in each of the last two categories. (Figure 2)

Among the circumstances of the injuries, most resulted from workplace accidents (36.84\%), with injuries in the home in second place, followed by car accidents, outdoor accidents, motorcycle accidents, attempted suicide (one case), and violence (one case) (Figure 3). Out of the total, 13.16\% were under the influence of alcohol (five patients - one who was run over, three in motor vehicle accidents, one of them on a motorcycle, and one who fell from a height at home).

More than half of the injuries occurred in the morning, a quarter of them in the afternoon, and the rest at night. (Figure 4)

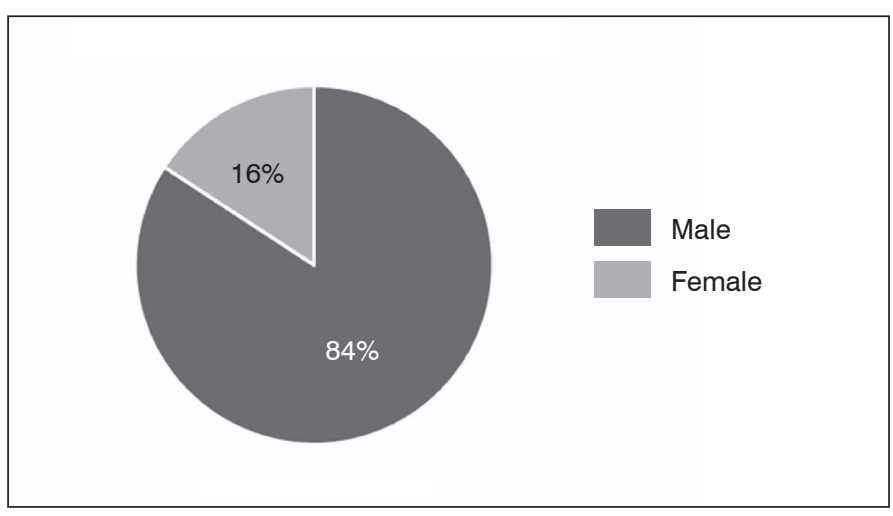

Figure 1. Distribution by sex. 


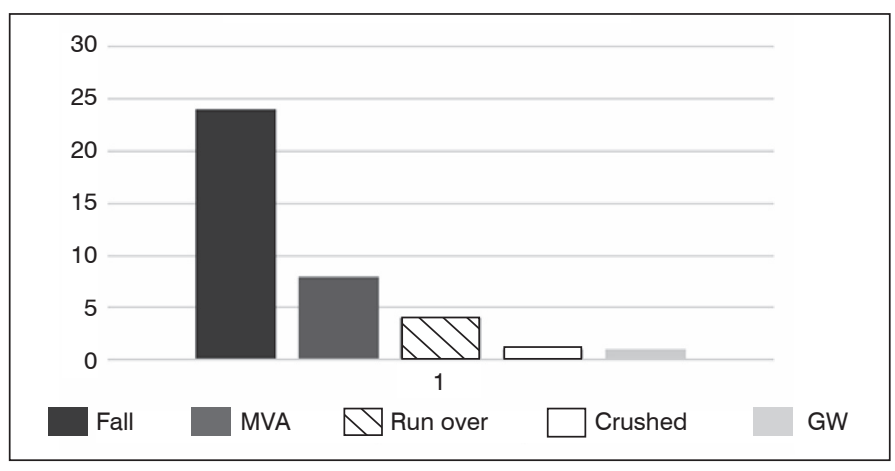

Figure 2. Injury Mechanism.

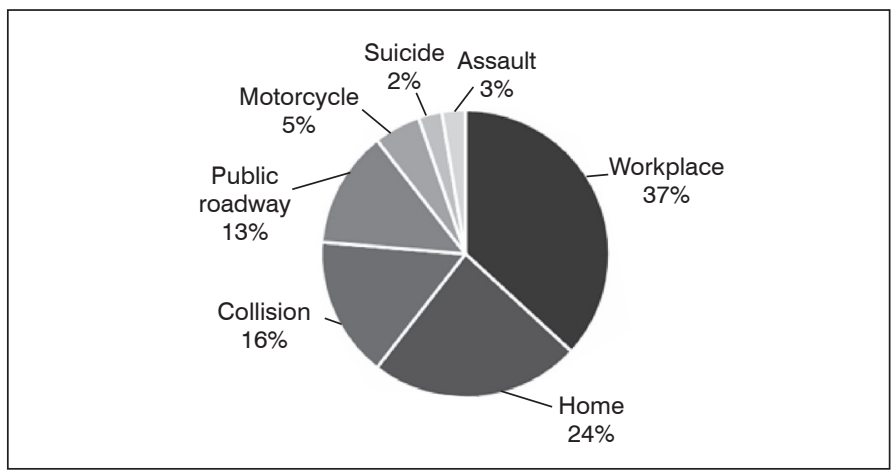

Figure 3. Type of Injury.

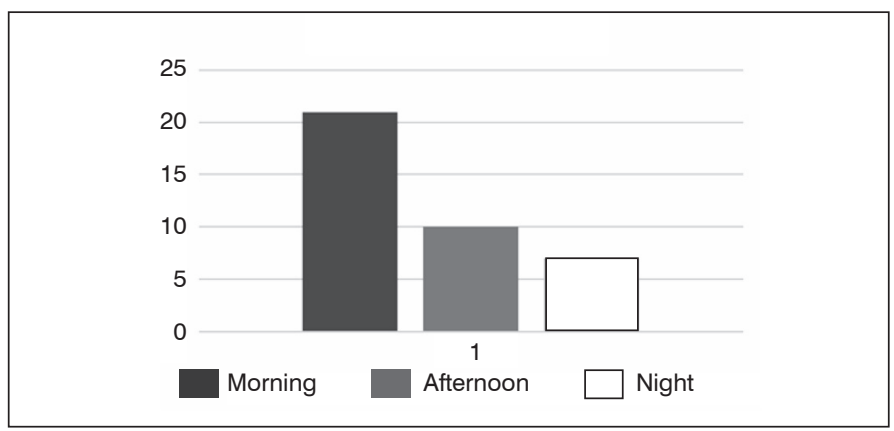

Figure 4. Time of injury.

\section{Distribution and classification of vertebral injuries}

Of the total number of patients included, six suffered vertebral injuries to two segments (15.79\%), 29 (76.23\% of the total) suffered some type of spine fracture, $12(31.58 \%)$ at the thoracic level and 3 (7.89\% of the total) at the cervical level. (Figure 5)

Figure 6 shows the distribution of vertebral injuries according to the $\mathrm{AO}$ classification system, with more than two thirds of the fractures classified as type $A$, a fourth of the fractures as type $B$, and one twentieth of the fractures as type C.

Among the cervical injuries, one was type $A$, one was type $B$, and one was type $\mathrm{C}$. Among the thoracic injuries, there were 7 type A fractures (58.33\%), 5 type B fractures (42.67\%), and no type C fractures. The lumbar fractures were comprised of 24 type $A(82.76 \%)$, 4 type B (13.79\%), and one type C fracture (3.45\%). (Figure 7 )

\section{Neurological involvement}

There were 9 patients with some kind of neurological involvement, representing $23.68 \%$ of the total study population, (Figure 8) 7 with incomplete lesions, one with radiculopathy, and one with complete lesion. (Figure 9)

More than three quarters of the total number of patients included were classified as Frankel E, followed by Frankel D, C, B, and A.

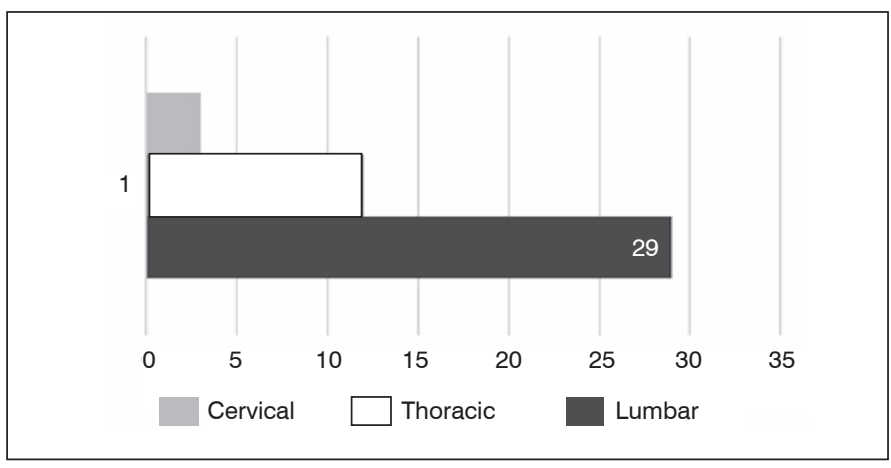

Figure 5. Distribution by segment.

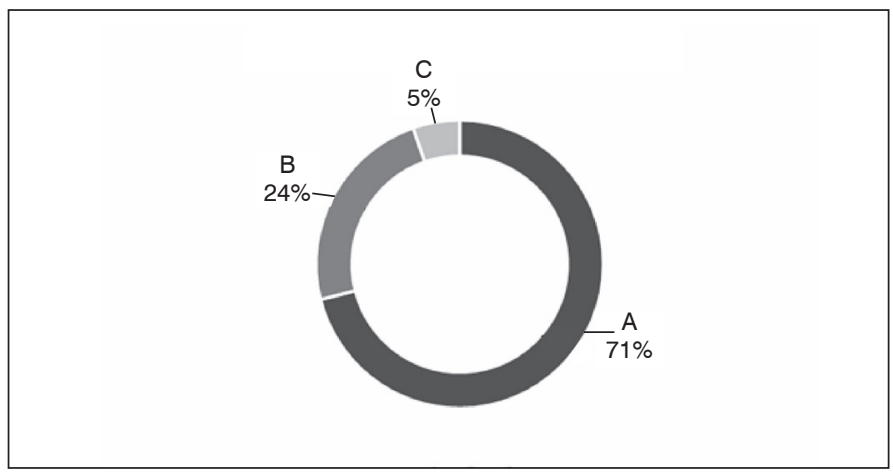

Figure 6. Vertebral injury by AO classification.

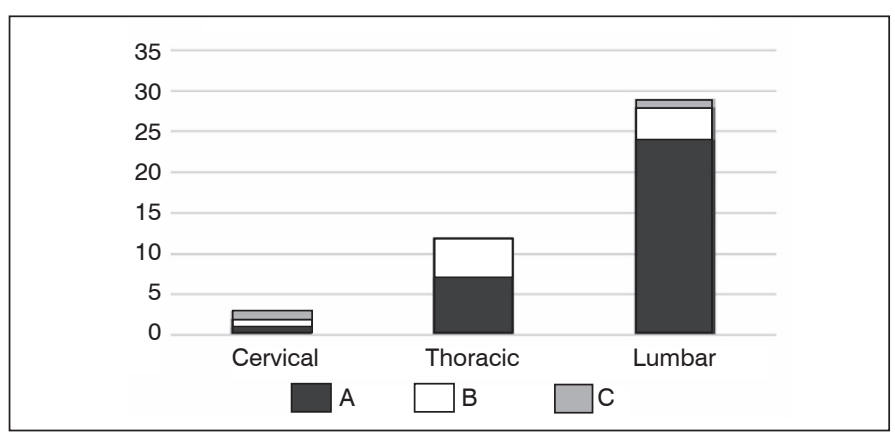

Figure 7. Distribution by $\mathrm{AO}$ classification.

In the distribution by segment, slightly more than two thirds of each group was classified as Frankel E. (Figures 10 and 11)

\section{Associated injuries (in addition to a fracture in any vertebral segment)}

The frequency of associated injuries showed a decreasing distribution, with about $45 \%$ of the patients with one associated injury, followed in order by patients with two, three, four, and five associated injuries. The most frequently affected segment was the thoracic members at $47.37 \%$, following by the pelvic members at $42.11 \%$, the pelvis at $36.84 \%$, the chest at $34.221 \%$, the skull and face at $31.28 \%$, and the abdomen at $21.05 \%$ of the total number of patients (Figure 12 and 13)

By segment, the patients with cervical spine injuries had a proportionally higher number of associated lesions, as three of them had 3 , 4 , or 5 associated injuries. The distribution by number of injuries was more uniform for patients with thoracic spine injuries with 1, 2, and 3 associated injuries, with a lower number of them with 4 associated injuries. The lumbar spine patients had the highest number of patients with the fewest number of associated injuries, with a lower distribution for 3, 4, and 5 associated injuries. (Figure 14)

By spinal segment affected, the patients with cervical injuries were more or less uniformly distributed across the skull, the chest, the 


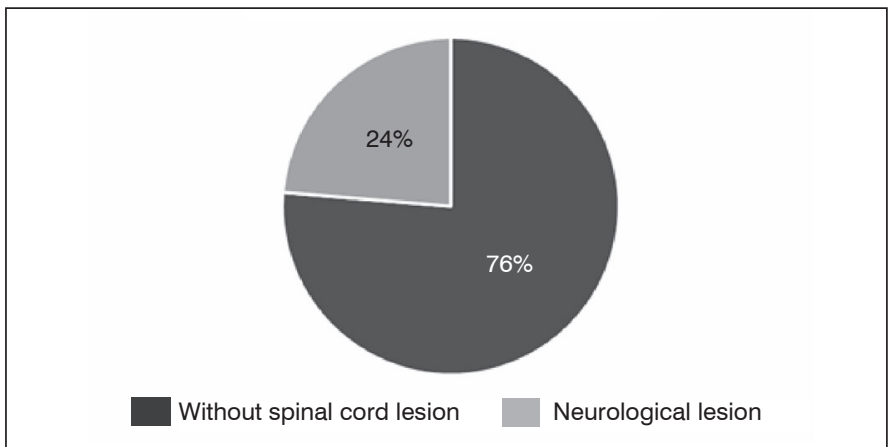

Figure 8. Neurological involvement.

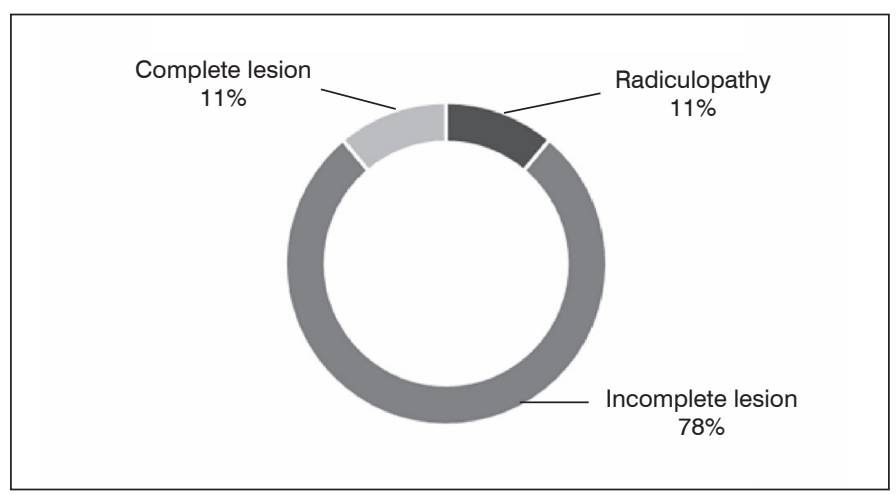

Figure 9. Total neurological lesions.

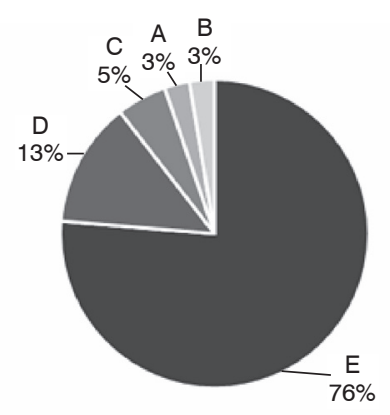

Figure 10. Frankel classification.

thoracic members, the abdomen, and the pelvis, without any injuries to the pelvic members. The patients with injuries to the cervical spine had a slightly higher incidence of associated injuries to the thoracic members. On the other hand, the patients with lumbar spine injuries had a higher incidence of associated injuries to the pelvic members, followed by the thoracic members. (Figure 15)

We included the relationship between the time of the injury and the number of associated lesions in this section, where we observed that the accidents of the patients with higher numbers of injuries occurred in the morning and in the afternoon. (Figures 16, 17, and 18)

\section{Treatment and complications}

Of the 38 patients in the study, 37 required at least one surgical procedure $(97.37 \%)$, with an average number of surgical procedures per patient, totalling 81 surgical procedures for all the patients included with a rate of infection of $7.41 \%$ (6 infections in total: two from open lumbar spine approaches, one from a minimally invasive lumbar spine approach, three from treatments of foot and ankle fractures, as well as one patient who developed a wound dehiscence from an abdominal approach). Instrumentation of some form (Caspar, Vertex, TSRH, Sextant, Legacy) was required for the spine injuries

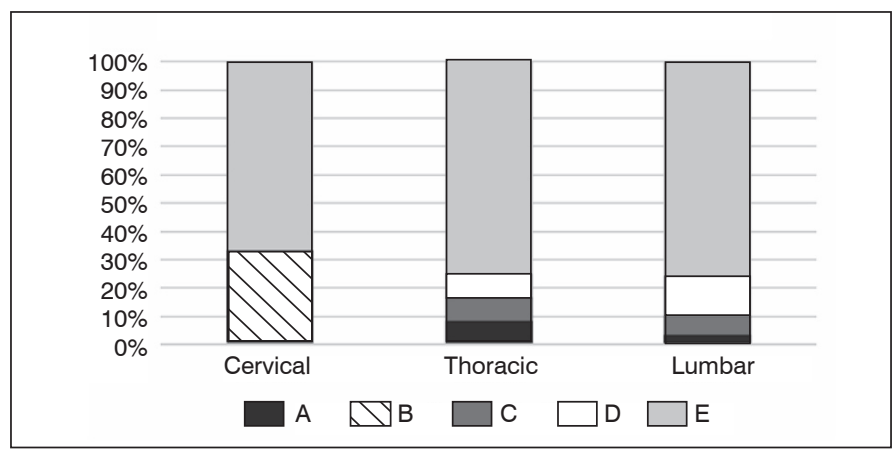

Figure 11. Distribution of neurological lesions by segment.

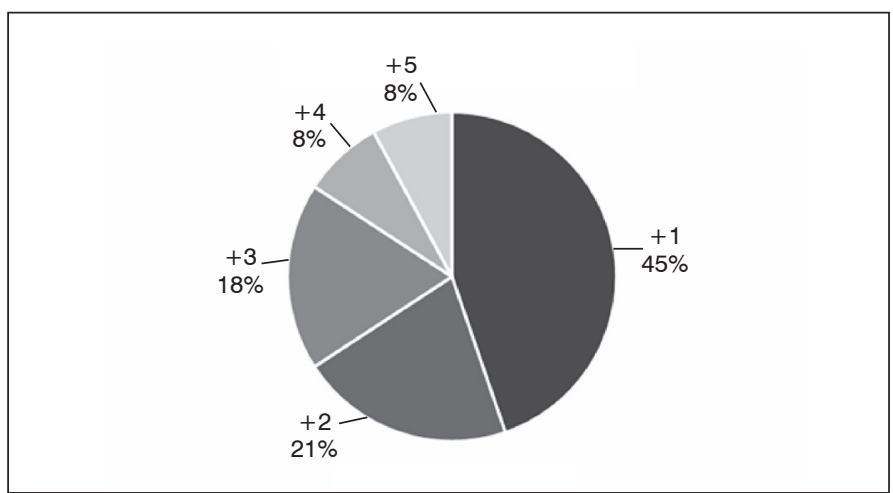

Figure 12. Associated injuries.

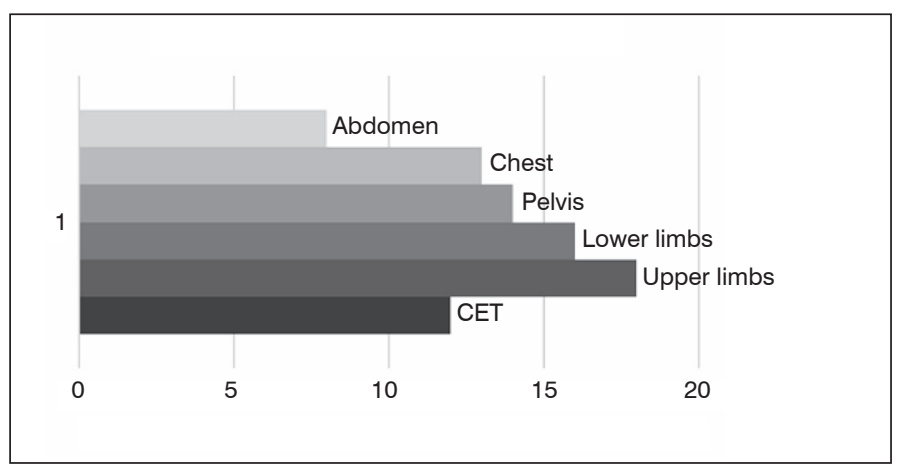

Figure 13. Total associated injuries.

of $68.43 \%$ (26) of the patients and $31.88 \%$ were managed with no surgical intervention (12 patients in total, 10 of whom were treated with the Jewett corset and two with just rest, one of them with a fracture from a gunshot wound and one with a transverse process fracture). (Figure 16)

\section{DISCUSSION}

In the general information of this study, a prevalence of the $16 \%$ period was found, about half compared to that reported by Laurer et al., ${ }^{1} 31 \%$. The difference between the incidence in men and women was greater than that reported by Leucht et al., ${ }^{2}$ who mentioned a ratio of $1.6: 1$ in contrast to the 5.3:1 ratio in our study. On the other hand, Chu et al. ${ }^{3}$ reported a ratio of almost $1: 1$ in a population of more than fifty thousand patients with vertebral injuries in Taiwan. The average age is similar to that reported by Leucht et al., ${ }^{2}$ who published a figure of 43.8 , similar to the 40.3 that we reported. The average number of days in the hospital of 8.5 days reported by Chu et al. $^{3}$ is less than our finding of an average of around two weeks, which implies a considerable hospital expense. 


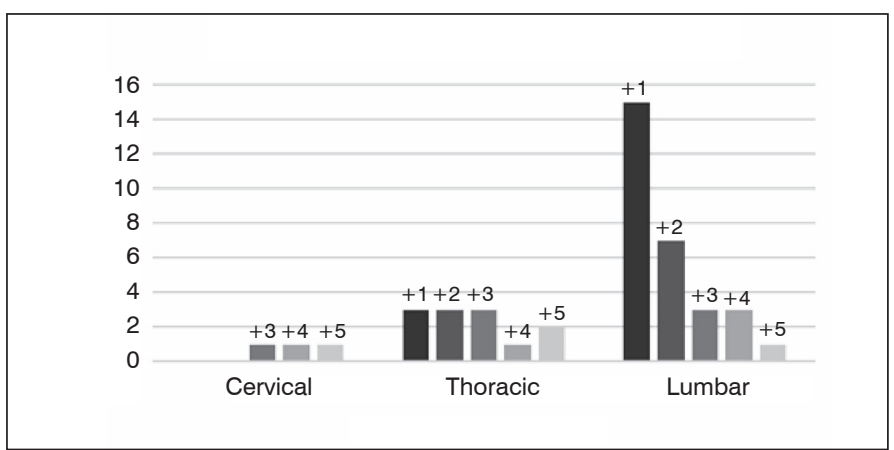

Figure 14. Distribution by segment and number of associated injuries.

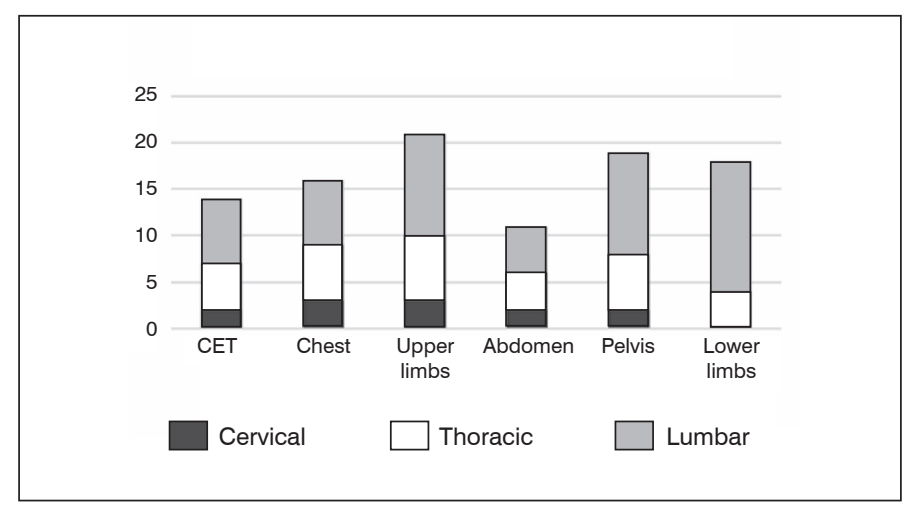

Figure 15. Distribution of vertebral injuries by body segment.

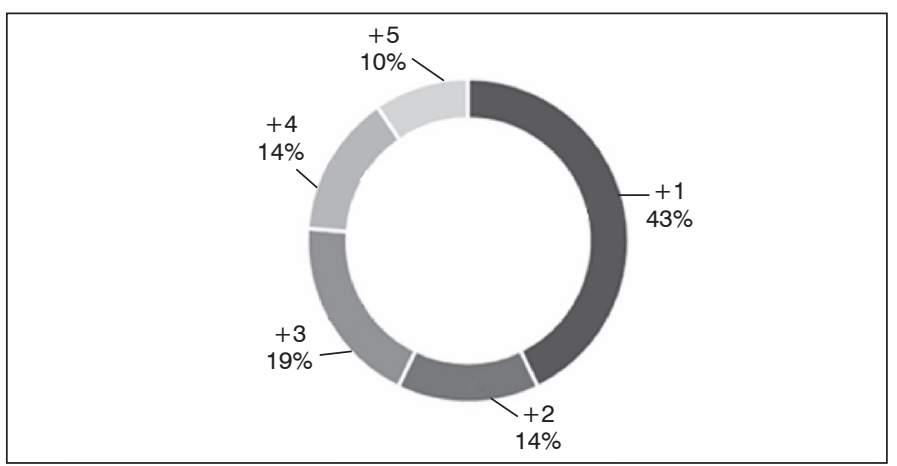

Figure 16. Morning

In terms of injury mechanisms, Leucht et al. ${ }^{2}$ divide falls into high-energy and low-energy, the former causing 39\% of the injuries and the latter causing $20 \%$, as different from Anwar, ${ }^{4}$ who reports motor vehicle accidents in first place at $37.4 \%$, falls at $24 \%$ (falls from heights), and falling down the stairs at $12.6 \%$. On the other hand, Laurer et al. ${ }^{1}$ report automobile accidents at $31 \%$, motorcycles at $12 \%$, and falls at a total of $40 \%$. We observed results similar to those of Leucht et al., ${ }^{2}$ with the combined percentage of falls at $63.16 \%$, followed by motor vehicle accidents at $21.05 \%$. It should be noted that this last figure is consistently lower than in other studies. These figures can not be directly compared with those reported by Browner et al., ${ }^{8}$ because they are of patients with isolated vertebral injuries, without regard to associated injuries (road accident $45 \%$, falls $20 \%$, recreational $15 \%$, violence $15 \%$, miscellaneous $5 \%$ ), however, gives us an idea of the differences and similarities between injurious mechanisms in both groups of patients.

The differences in the injury mechanisms involved in thoracolumbar spine injuries should be emphasized, since it is reported that more than $50 \%$ are due to motor vehicle accidents. ${ }^{7}$ Although these isolated segments were not analyzed directly in this study, the difference can be inferred by considering that more than $90 \%$ of the

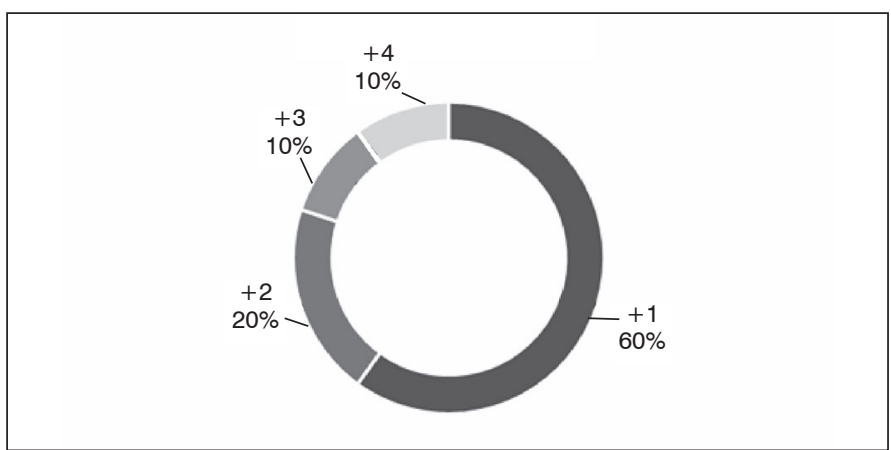

Figure 17. Afternoon.

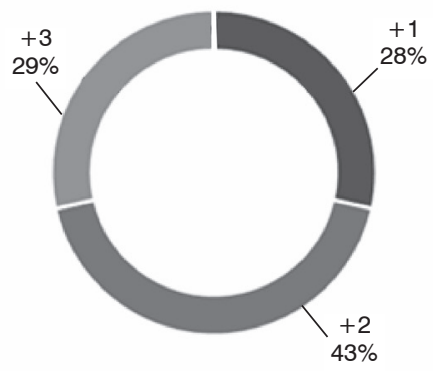

Figure 18. Night.

patients included in our study had an injury in that segment and the most common injury mechanism $(63,16 \%)$ was falls.

In other studies, there is no mention of the conditions of the injury. In our population, we observed that most were work-related accidents, followed by accidents in the home, and in lesser proportions collisions and accidents in public roadways. It is of interest that only two out of the total number of patients included had motorcycle accidents. As for the time of day, the distribution coincided with the frequency of work accidents, most of them occurring during the morning hours. According to these results, we found that the patients with the highest number of associated injuries were injured during the morning and afternoon hours, while there was a lesser quantity of associated injuries during the nighttime hours.

In terms of the distribution of vertebral injuries, lumbar injuries accounted for more than half of the total, just as in the studies by Leucht et al. ${ }^{2}$ and Chu et al. ${ }^{3}$ who reported them at $50.4 \%$ and $57 \%$, respectively. Anwar, ${ }^{4}$ by contrast, reports cervical injuries with an incidence of $42.6 \%$, quite probably as secondary due to the great number of vehicular accidents suffered by his population.

Of the total vertebral injuries according to the $\mathrm{AO}$ classification, the distribution for the thoracic and lumbar spines coincides with that reported by Leucht et al. ${ }^{2}$ it is not possible to make a correlation for the cervical spine due to the small number of patients that we found. In total, the proportion that we observed for the total number of type $A$ fractures was considerably higher than that reported by Leucht et al. ${ }^{2}$

As for neurological lesions, the incidence is similar to that reported by Leucht et al., ${ }^{2}$ Chu et al., ${ }^{3}$ and Laurer et al. ${ }^{1}$ (24.7\%, 27.6\%, and $24.6 \%$ respectively), and the distribution by Frankel classification, in total, is similar to that reported previously. The distribution by segment according to the Frankel classification is relatively uniform for Frankel $\mathrm{E}$.

There is a considerable difference in the incidence of associated injuries in general, being significantly higher in our population, for example, for fractures of the extremities (total of $26.63 \%$ reported by Leucht et al., ${ }^{2} 23 \%$ by Saboe et al, ${ }^{5}$ versus $41.98 \%$ in our study). In regards to craniofacial injuries, the data are not consistent, Leucht et al. $^{2}$ reporting an incidence of $19.3 \%$, Saboe et al. ${ }^{5}$ of $26 \%$, and our study of $31.58 \%$. On the other hand, the incidence of 
double vertebral injuries was slightly less (21.3\%, according to Leucht et al., ${ }^{2}$ as compared to $15.79 \%$ in this study).

The distribution of associated injuries by segment affected is similar to that reported in other studies, being higher for pelvic members and the pelvis in the patients with lumbar injuries and proportionally uniform for injuries to the skull, chest, and thoracic members in the patients with cervical injuries. The patients with thoracic injuries had a more or less even distribution with a slightly higher incidence of injuries to the thoracic members, as reported by Chu et al. ${ }^{3}$

In reports that analyze this population, there was no mention of the time of injury. We found a higher incidence of associated injuries in patients who suffered accidents in the morning and afternoon timeframes, which probably only reflects the quantitative difference between patients injured at these times.

In terms of performing a surgical procedure of the spine, Chu et al. ${ }^{3}$ report that $17.3 \%$ of their patients required a surgical procedure is this region, while in our sample we found $68.42 \%$. This data could be biased because the study by Chu et al. ${ }^{3}$ initially referred to the total number of patients admitted to any hospital unit in Taiwan secondary to any vertebral injury, unlike our population which only considered those patients who were hospitalized in the Polyfractures Service, given that most of the patients who are candidates for conservative management are discharged from the Urgent Care Service and only those patients requiring a surgical procedure remain hospitalized.

The rate of infection of the surgical site reported in the literature is around $2.9 \%$, Canale $^{5}, 2013$ and in our study, we observed a rate of more than twice that rate, at $7.41 \%$. This increase is attributable to the presence of multiple injuries in the polyfractured patients that imply a great metabolic demand and an altered immunological response, predisposing the patient to experience both infection and dehiscence of the wound or consolidation failure.

\section{CONCLUSION}

The most important injury mechanism in this study was falls, which accounted for the majority of cases in the work environment. The severity of the associated injuries that we found is greater than that reported in Taiwan, in the United Kingdom, and in Germany, and might reflect the work conditions of the Mexican labor force.

We found that the most frequently associated injuries occur in the thoracic and pelvic members, and that patients with cervical injuries have a higher number of associated injuries. The patients with lumbar injuries had a higher incidence of injuries to the pelvic members and the patients with injuries to the thoracic spine had a relatively uniform distribution of associated injuries.

We found that the rate of infection was more than double that reported in the literature, attributable to the higher metabolic demand to which the patient with multiple trauma is subjected.

This study is a starting point for the realization of studies focused on polytraumatized patients in the Mexican population.

All authors declare no potential conflict of interest related to this article.

CONTRIBUTION OF THE AUTHORS: Each author made significant individual contributions to the development of this manuscript. LM and RA were the main contributors to the compilation of the bibliography, the analysis, and the writing of the paper. YM and RA were in charge of reviewing the patient log for the building of the database. RA reviewed the clinical case files to be loaded into the database. LM and YM conducted the final review and approval of the manuscript.

\section{REFERENCES}

1. Laurer H, Maier B, El Saman A, Lehnert M, Wyen H, Marzi I. Distribution of Spinal and Associated Injuries in Multiple Trauma Patients. Eur J Trauma Emerg Surg. 2007;33(5):476-81.

2. Leucht $P$, Fischer K, Muhr G, Mueller EJ. Epidemiology of traumatic spine fractures. Injury. 2009:40(2):166-72.

3. Chu D, Lee YH, Lin CH, Chou P, Yang NP. Prevalence of associated injuries of spinal trauma and their effect on medical utilization among hospitalized adult subjects-a nationwide data-based study. BMC Health Serv Res. 2009;9:137.

4. Anwar F, Multiple trauma associated with spinal injury. RMJ. 2011;36 (1):18-21.
5. Saboe LA, Reid DC, Davis LA, Warren SA, Grace MG. Spine trauma and associated injuries. J Trauma. 1991:31(1):43-8.

6. Canale T, Beaty J, Cleveland K. General principles of infection. In: Canale ST, Beaty JH. Campbell's operative orthopaedics. 12th ed. New York: Elsevier; 2013. p. 706-23.

7. Herlowitz H, Garfin S, Eismons F, Bell G, Balderston R, Agabegi. Rothman-Simeone: the spine. New York: Elsevier; 2011.

8. Browner B, Gupta M, Benson D, Keenen T. Initial evaluation and emergency treatment of the spine injured patient. In: Browner BD, Jupiter JB, Kretteck C, Anderson PA, editors Skeletal trauma. New York: Elsevier; 2015. p. 729-51. 